\title{
Cost of Capital: Literatures Review about Calculation Methods and Influencing Factors
}

\author{
Huihui Li \\ Institute of Economics, Jinan University, Guangzhou, China \\ Email:jnu_lihuihui@163.com
}

How to cite this paper: Li, H.H. (2019) Cost of Capital: Literatures Review about Calculation Methods and Influencing Factors. Journal of Service Science and Management, 12, 360-370. https://doi.org/10.4236/jssm.2019.123024

Received: February 28, 2019

Accepted: April 8, 2019

Published: April 11, 2019

Copyright (c) 2019 by author(s) and Scientific Research Publishing Inc. This work is licensed under the Creative Commons Attribution International License (CC BY 4.0).

http://creativecommons.org/licenses/by/4.0/

\begin{abstract}
As one of the core concepts of corporate financial management, on the one hand, cost of capital is the cost of corporate financing and related to the financing behavior of firms, on the other hand, cost of capital is the necessary rate of return for investors, which decides investment activities. How to calculate cost of capital? What are the influencing factors for cost of capital? These two questions will play a fundamental role in judging whether cost of capital is high in China and promoting the cost reduction task proposed by the current supply-side reform.
\end{abstract}

\section{Keywords}

Cost of Capital, Influencing Factors, Literatures Review

\section{Introduction}

As China has entered a new stage, economy growth has shifted from high speed to medium-high speed. In view of the current economic situation, the central economic working group creatively put forward a new strategy of supply-side structural reform at the central economic work conference in December 2015, and further defined the economic work deployment of supply-side structural reform as five tasks, among which cost reduction has been repeatedly emphasized. Whether cost of capital in China has already fell? How can we reduce cost of capital? To answer these questions, the first job is to calculate the cost of capital and find out its influence factors, Chinese scholars have done much in calculating cost of capital and studying the relationship between one certain factor and cost of capital. However, different scholars used different measuring methods and studied different factors. What's more, they have done less in literatures review so they can't understand the whole thing. To make up for the lack 
of previous literatures, this article sorts out the literatures from the aspects of capital cost calculation methods and influencing factors, summarizes all the calculating methods and concludes the influencing factors of capital cost which provides a comprehensive view for us. By comparing various calculation methods, we can know the robustness of them and summarization of influencing factors can provide some suggestions to the cost reduction task.

The article is organized as follows: Section 2 introduces the calculation methods of capital cost including average cost of capital, weighted average cost of capital (WACC) and internal rate of return (IRR), in which WACC is most widely used. Section 3 summarizes the influencing factors of capital cost, such as operation and governance of the company, information disclosure, external macro environment and other factors. Section 4 concludes the article and Section 5 is references.

\section{The Calculation Methods of Capital Cost}

As one of the core concepts of corporate financial management, on the one hand, cost of capital is the cost of corporate financing and is related to firm's financing behavior. According to the "financing priority" theory, when a firm needs financing, the first consideration is internal financing while equity financing is secondary. In addition, the cost of debt capital and equity capital also determines the financing structure of firms. On the other hand, the cost of capital is the necessary rate of return for investors, which is related to the investment decision of firms. Taking the cost of capital as the discount rate, if the net present value of a project is lower than 0 , then the project is not worth investing, because the investment income cannot offset the cost of financing; If the net present value is greater than or equal to zero, then the investment is profitable and the project is worth investing in. As a bridge connecting both investment and financing and investors and managers, cost of capital plays an important role in corporate finance. There are three main methods to measure the cost of capital in relevant literatures: average cost of capital, weighted average cost of capital and internal rate of return.

\subsection{Average Cost of Capital}

This method was first proposed by Miller \& Modigliani [1], which established a model based on the relationship between firm value and capital cost:

$$
(V-\tau D)=\alpha_{1}+\alpha_{2} \bar{X}(1-\tau)+\alpha_{3} \overline{\Delta A}+U
$$

where, $V=$ the current value of the firm, $\bar{X}=$ the expected return, $\tau=$ corporate tax rate, $D=$ the value of debt, $\overline{\Delta A}=$ the change of assets, $U=$ the random disturbance term.

Since the random disturbance term is related to the firm size, there may be heteroscedasticity. To solve the problem, Miller and Modigliani adjusted each variable with the firm scale, namely the book value of the total assets $A$, thus: 


$$
\frac{(V-\tau D)}{A}=\alpha_{1}^{\prime}+\alpha_{2} \frac{\bar{X}(1-\tau)}{A}+\alpha_{3} \frac{\overline{\Delta A}}{A}+\mu
$$

In theory, the inverse of the parameter $\alpha_{2}$ should be the cost of equity capital. However, in fact, after introducing firm size to the model, firm size becomes an explanatory variable too, which affects the correctness of the model. Therefore Miller and Modigliani adopted two-stage estimation methods, in the first stage, they find five instrumental variable: firm size, growth, asset liability ratio, preferred stock and assets ratio, dividends and capital ratios as explanatory variables and $\bar{X}$ as explained variable, then establish a regression equation with zero intercept and estimate the coefficient. Raw data of the five instrument variables and the coefficient can give new expected earnings. In the second stage, the new expected earnings obtained in the first stage are substituted into the Equation (2), the parameters $\alpha_{2}$ are estimated and the cost of equity capital

$\rho_{k}=\frac{1}{\alpha_{2}}$. Considering the debt tax shield, the average cost of capital can be expressed as:

$$
C=\rho_{k}\left(1-\tau \frac{\mathrm{d} D}{\mathrm{~d} A}\right)
$$

Chinese literature also used this method to calculate the equity capital cost of department stores in the stock market from 1995 to 1997 [2]. Based on this method, they calculated the capital cost and found that both the equity capital cost and the average capital cost showed a downward trend. In addition, the cost of equity capital is higher than that of debt, especially in 1995 and 1996. By the way, this method is not widely used these years.

\subsection{Weighted Average Cost of Capital (WACC)}

In the standard financial textbooks, there is the weighted average cost of capital method, which calculates cost of capital equal to a weighted average cost of debt capital and equity:

$$
\mathrm{WACC}=r_{e}\left(1-w_{d}\right)+r_{d} w_{d}
$$

the method is popular, but scholars have different views. on three variables involved in the equation.

\subsubsection{Debt Capital Cost $\left(r_{d}\right)$}

The cost of debt capital is relatively simple and less controversial than the cost of equity capital. On the one hand, due to debt tax shield, the cost of debt capital is generally lower than that of equity capital; On the other hand, the weight of debt in total financing is relatively small. Therefore, the cost of debt capital has a smaller impact on the cost of capital and there are relatively few studies on this part.

Cost of debt capital is generally considered to be equal to interest expenditure/debt [3] [4] [5] [6]. This method defines cost of debt capital as: 


$$
r_{d}=\frac{E_{f}+E_{c}}{D}(1-t)
$$

where $E_{f}$ is expensed interest expense, $E_{c}$ is capitalized interest expense, $D$ is debt and $t$ is income tax rate. [3] [5] defined $D$ as the average total debt, [6] defined $D$ as the average interest-bearing debt while [7] and [8] defined $D$ as the average of initial and final loan amount. In addition, [9] used a variety of methods to calculate the cost of debt capital. However, these methods are not much different in fact. What's more, because the weight and the cost of debt capital are small relative to that of equity capital, these methods have similar results.

In addition, the bond yield to maturity method is used in standard financial textbooks, which is applicable to a single bond. Since most firms issue bonds in different periods with different maturities, so the method is rarely used in actual academic research.

\subsubsection{Cost of Equity Capital $\left(r_{e}\right)$}

There are abundant literatures for calculating the cost of equity capital, and the classic methods are CAPM, multi-factor Model, APT. there is the Dividend-discount Model in standard financial textbooks:

$$
P_{t}=\sum_{i=1}^{\infty} \frac{E_{t}\left(D_{t+i}\right)}{\left(1+r_{e}\right)^{i}}
$$

where $P_{t}$ is the price per share at the beginning of period $t, D_{t+i}$ is the dividend per share in period $t+i$, and $r_{e}$ is the cost of equity capital.

When dividends growth is stable, the dividend discount model can transformed into the Gordon growth model:

$$
P_{0}=\frac{D_{1}}{K_{s}-g} \rightarrow K_{s}=\frac{D_{1}}{P_{0}}+g
$$

where $D_{1}$ is the dividend per share in the first year in the future, $P_{0}$ is the market price per share at the beginning of the year, $g$ is dividend growth and $K_{s}$ is the cost of equity capital. On the basis of dividend discount model, [10] assumed that income and market value of firm met the clean surplus relationship, so the Equation (6) can be converted to:

$$
P_{t}=B_{t}+\sum_{i=1}^{\infty} \frac{E_{t}\left[N I_{t+i}-r_{e} B_{t+i-1}\right]}{\left(1+r_{e}\right)^{i}}=B_{t}+\sum_{i=1}^{\infty} \frac{E_{t}\left[\left(R O E_{t+i}-r_{e}\right) B_{t+i-1}\right]}{\left(1+r_{e}\right)^{i}}
$$

$P_{t}:$ the price of the stock at period $t$

$B_{t}:$ the face value at period $t$;

$N I_{t+i}$ : net income at period $t+i$;

$r_{e}:$ cost of equity capital;

$R O E_{t+i}$ : the after-tax return on the book equity in the period $t+i$.

If the value after the third period is taken as the final value, the above equation can be rewritten as: 


$$
P_{t}=B_{t}+\frac{F R O E_{t+1}-r_{e}}{\left(1+r_{e}\right)} B_{t}+\frac{F R O E_{t+2}-r_{e}}{\left(1+r_{e}\right)^{2}} B_{t+1}+T V
$$

the final value $T V=\sum_{i=3}^{T-1} \frac{F R O E_{t+i}-r_{e}}{\left(1+r_{e}\right)^{i}} B_{t+i-1}+\frac{F R O E_{t+T}-r_{e}}{\left(1+r_{e}\right)^{T-1} r_{e}} B_{t+T-1} . F R O E_{t+i}$ is the predicted value of $R O E_{t+i}$, they compute this variable as $e p s_{t+i} / B_{t+i}$, where $e p s_{t+i}$ is the expected earnings per share in the period $t+i . B_{t+i}$ is the book value in period $t+i$, which met $B_{t+i}=B_{t+i-1}+e p s_{t+i}-d p s_{t+i}$, where $d p s_{t+i}$ is the expected dividend per share in period $t+i$. Assuming the prediction period is 12 , then the final value is:

$$
T V=\sum_{i=3}^{12} \frac{F R O E_{t+i}-r_{e}}{\left(1+r_{e}\right)^{i}} B_{t+i-1}+\frac{F R O E_{t+12}-r_{e}}{\left(1+r_{e}\right)^{11} r_{e}} B_{t+11}
$$

Combining firm's financial data and forecast data of analyst, then obtains the cost of equity, this is the residual income discount model (GLS). This method implies the assumption that the expected cost of equity capital is equal to the actual cost of equity capital $r_{e}$.

[11] constructed a PEG model in which the cost of equity capital was the square root of the inverse PEG ratio, and modified the PEG model to establish an MPEG model in which the modified cost of equity capital was the square root of the inverse PEG ratio. Based on the two models, two indexes for calculating the cost of equity capital are proposed:

$$
\begin{gathered}
r_{P E G}=\sqrt{\frac{e p s_{t}-e p s_{t-1}}{P_{t-2}}} \\
r_{M P E G}=\sqrt{\frac{e p s_{t}+r_{M P E G} e p s_{t-1}-e p s_{t-1}}{P_{t-2}}}
\end{gathered}
$$

$e p s_{t}$ is the earnings per share at period $i$ forecasted by analysts. [12] proposed OJN model and obtained the expression of equity capital cost

$$
r_{e}=A+\sqrt{A^{2}+\frac{e p s_{1}}{p_{0}}\left[\frac{e p s_{2}-e p s_{1}}{e p s_{1}}-(\gamma-1)\right]}
$$

where $A=\frac{\gamma-1+d p s_{1} / P_{0}}{2}, \gamma=g_{P}+1 . e p s_{1}$ is expected net income per share after one year, $e p s_{2}$ is the expected net income per share after two years, $d p s_{1}$ is the expected dividend per share after one year and $P_{0}$ is the current stock price. $g_{p}$ is the long-term growth rate of net profit after two years and $\left(e p s_{2}-e p s_{1}\right) / e p s_{1}$ is a proxy generally.

[13] put forward the abnormal returns model (CT) in which returns in different periods will satisfy different equations. This method is consistent with GLS, assuming that firms meet the clean surplus relationship, then:

$$
P_{0}=B_{0}+\sum_{t=1}^{\infty}\left[\frac{a e_{t}}{\prod_{s=1}^{t}\left(1+r_{f s}+r p\right)}\right]
$$


where $P_{0}$ is the current stock price, $B_{0}$ is the current book value, $a e_{t}$ is the expected return, $r_{f s}$ is the one-year risk-free interest rate in period $s, r p$ is the equity risk premium, and the cost of equity capital $k=r_{f}+r p$. Assuming that the income is abnormal, the expected income in the first five years satisfies the equation $a e_{t}=e_{t}-b v_{t}\left(r_{f t}+r p\right)$ while from the sixth year onwards it equals $a e_{5}\left(1+g_{a e}\right)^{t-5}$, where proxy variable for $g_{a e}$ is the yield to maturity of the ten-year Treasury bond. Then the Equation (14) can be further arranged to obtain:

$$
P_{0}=B_{0}+\sum_{t=1}^{5} \frac{e_{t}-r_{e} * b v_{t-1}}{\left(1+r_{e}\right)^{t}}+\frac{\left(e_{5}-r_{e} * b v_{4}\right)\left(1+g_{a e}\right)}{\left(1+r_{e}\right)^{5}\left(r_{e}-g_{a e}\right)}
$$

The above are the main methods to calculate the cost of equity capital. Earlier Chinese literatures tend to use the CAPM method [14] or the historical average stock return rate as an alternative to the cost of equity capital [15], while more literatures in recent years used GLS [16] [17] PEG and MPEG [18] [19] [20] and OJ model [21]. In recent years, some scholars have adopted a variety of methods to calculate the cost of equity capital and finally obtained an average value of those [5] [6] [16] [22]. As GLS model as well as CT model, all need the longer-term forecasts and [23] found that PEG model have the highest estimated validity in PEG, OJ model and dividend discount model, PEG model is popular in calculating the cost of equity capital.

\subsubsection{The Weight $\left(w_{d}\right)$}

As for the weight of debt capital in total financing, the calculation method is relatively simple. One method starts from the actual financing structure, while the other method starts from the target financing structure. The first method bases that debt capital should adopt book value and equity capital should adopt market value. The current ratio of debt capital is the weight of debt capital due in the process of corporate financing, so the weight is equal to current debt capital divided by the sum of current debt capital plus equity capital. The second approach assumes that the weighted should be the target structure, which is the best estimate of how to raise funds in the future. In addition, both debt capital and equity capital should be weighted by the actual market value. Due to simplicity of operation and availability of data, the first method is commonly used, while the second method is the theoretical method in financial textbooks, because it is difficult to obtain information about the future and make realistic estimates of the future.

\subsection{Internal Rate of Return}

In addition to the above two methods for calculating the cost of capital, [24] used a clever method to calculate the cost of capital of listed companies from 1950 to 1996. Fama and French regarded the entire stock market as a large investment project and established an inclusive equation based on the relationship of overall cost and return: 


$$
I C_{0}=\sum_{t=1}^{T(1996)} \frac{X_{t}-I_{t}}{\left(1+r_{c}\right)^{t}}+\sum_{t=1}^{T(1996)} \frac{F S_{t}-F B C_{t}}{\left(1+r_{c}\right)^{t}}+\frac{T V_{1996}}{\left(1+r_{c}\right)^{T}}
$$

$r_{c}$ is the cost of capital, the other variables involved in the equation are: $I C_{0}$, the total cost of the assets in the initial period; $X_{t}$, total cash income which is after-tax income but does not deduct depreciation and interest; $I_{t}$ total investment which including net investment and depreciation. $F S_{t}$, the final market value of the sample left during the period $t ; F B C_{t}$, the initial cost when entering the sample in the future; $T V_{1996}$, the market value of the sample firm still remains at the end of the sample period (1996). Combined with the cash flow equation, the net cash inflow $X_{t}-I_{t}$ in the above equation can be decomposed into dividends Div $v_{t}$ plus interest expenditure Int minus newly issued securities $N S_{t}$, thus the equation can be converted into:

$$
I C_{0}=\sum_{t=1}^{T(1996)} \frac{D i v_{t}+I n t_{t}-N S_{t}}{\left(1+r_{c}\right)^{t}}+\sum_{t=1}^{T(1996)} \frac{F S_{t}-F B C_{t}}{\left(1+r_{c}\right)^{t}}+\frac{T V_{1996}}{\left(1+r_{c}\right)^{T}}
$$

The cost of capital $r_{c}$ can be obtained by substituting the variable data of the whole stock market into the above equation. [25] calculated the capital cost of China's a-share market from 1990 to 2001 as 7.52\% based on this method. As this method needs a long sample period while Chinese stock market has established for about only 30 years, IRR is not much proper in China. In addition, [26] estimated marginal $q$ and marginal return, then based on the relationship of marginal cost, marginal return and marginal $q$ to calculate cost of capital indirectly.

\section{The Influence Factors of Capital Cost}

In modern corporate finance theory, the cost of capital has a significant impact on the investment and financing activities of firms. Cost of capital plays such an important role, so what influences the cost of capital of firms? Based on the literatures, this paper can roughly divided them into the following categories: corporate governance, external macro environment, information disclosure and other factors.

\subsection{Operation and Governance of the Company}

Ownership and management are separated in modern companies, this can give play to the capital ability of investors and management ability of managers, but also causes the information asymmetry between investors and managers. Managers know more about the actual situation of firms than investors. Due to the different position, the manager's profit maximization and the maximization of the value of corporate is not always consistent. The existence of information asymmetry promotes managers more likely to maximize his own interest while damage profit of investors. For their own personal interests, managers may make irrational investment decisions, which increase the cost of capital. 
This aspect mainly includes the following several angles, the first is the incentive, the supervision and the internal control. [27] found that the financial supervision and incentive mechanism has a significantly negative impact on the cost of equity capital, and improving the financial supervision and incentive efficiency can effectively reduce the cost of equity capital. According to [28], equity incentive does not enhance corporate governance to reduce the cost of capital. On the contrary, it increases the management's possession of corporate value and thus increases the cost of capital. [8] found that the better the internal control quality, the lower the debt capital cost of the corporate. [29] studied the impact of cash dividend distribution on the cost of equity capital and the results showed that the more dividends distributed, the lower the cost of equity capital.

The second is the earnings management perspective. [15] shows that the higher the quality of earnings, the lower the cost of capital. [30] selected sales control, production control and discretionary cost control from the opposite perspective, and found that the three have a positive impact on the cost of equity capital. [15] on the basis of previous studies divided firms into two categories according to the firm's growth, and then studied the real impact of surplus management on the cost of equity capital respectively. Real earnings management makes the cost of equity capital down for high growth firms, while rise the cost for the low growing company.

Finally, the diversification perspective, [14] found that although diversification is positively correlated with the cost of equity capital of firms, it is negatively correlated with the total cost of firms, that is, the diversification of firms can reduce the cost of capital of firms. The research of [17] shows that with the increase of the uncertainty of the external environment of firms, the impact of diversification on the cost of capital is first positive and then negative.

\subsection{Information Disclosure}

The influence of information disclosure on the cost of capital is mainly considered from the positive and negative perspectives in previous literatures. First, more information disclosure will enable investors to better understand the actual situation of firms and reduce information asymmetry, thus reduce the cost of capital. Second, when information disclosure is limited, investors will have more uncertainty about their expectations of future returns, thus increasing investment risks. Therefore, investors will demand higher rate of return. [31] has sorted out these two types of literatures in detail. [32] took earnings conservatism as the proxy variable of information disclosure quality and found that the higher the degree of information disclosure, the lower the capital cost of the corporate. [16] found that disclosure of internal control self-evaluation and verification report can significantly reduce the cost of capital. The empirical results of the paper by [33] shows that the verification of social responsibility report can reduce the cost of equity capital and in firms with poor information disclosure quality, the cost of equity capital is reduced more significantly. 


\subsection{External Macro Environment}

The operation and management of micro-firms cannot be separated from the macro-economy, and the cost of capital is inevitably affected by the macro-economic environment, such as economic system and economic uncertainty. [34] constructed the investor protection execution index and found that the index was significantly negatively correlated with the company's debt ratio. In other words, the more thoroughly the investor protection was implemented, the higher the proportion of equity capital would be. This indirectly proves that the impact of investor protection on the cost of equity capital is negative. [7] studied the impact of private credit discrimination on cost of debt capital and found that the cost of debt capital in private firms was higher than that of non-private firms, and they two did not converge over time which means private credit discrimination exists and did not improve. [17] introduced environmental uncertainty into the econometric model, and empirically found that environmental uncertainty had a positive impact on the cost of capital, which may be because uncertainty increased the investment risk of investors, thus requiring a higher rate of return to compensate.

\subsection{The 0thers}

In addition to the above three main aspects, there are some other factors, such as CEO financial experience [9], analyst analysis [16], M \& A goodwill [35], corporate financing scale, corporate social responsibility information disclosure and other factors that affecting the cost of capital.

\section{Conclusion}

This article reviews the literatures about calculation methods and influencing factors of capital cost, which gives us a comprehensive view. To be more specific, the article compares all the calculation methods and elaborates the relationships and differences among them, what's more, it reviews their popularity in China. Calculation methods are abundant and using different methods to calculate the cost of capital can test the robustness of methods. Besides, the article also concludes the factors which influence cost of capital significantly, such as operation and governance of the company, information disclosure, external macro environment and so on. Previous literatures only analyze the influence of a single factor and pay little attention to the joint effect. In next, in one way, we can calculate cost of capital in different ways to make sure the validity of calculation, in other way we should actively explore other influencing factors and pay more attention to the joint effect of influencing factors rather than influence of a single one, which is useful for evaluating and reducing cost of capital and responding positively to calls put forward by supply-side structural reform.

\section{Conflicts of Interest}

The author declares no conflicts of interest regarding the publication of this 
paper.

\section{References}

[1] Miller, M.H. and Modigliani, F. (1966) Some Estimates of the Cost of Capital to the Electric Utility Industry, 1954-57. The American Economic Review, 57, 333-391.

[2] Shen, Y. and Tian, J. (1999) Quantitative Research on Cost of Capital of Listed Companies in China. The Economic Research, 62-68.

[3] Pittman, J.A. and Fortin, S. (2004) Auditor Choice and the Cost of Debt Capital for Newly Public Firms. The Journal of Accounting \& Economics, 37, 113-136.

[4] Garcíameca, E. (2011) Ownership Structure and the Cost of Debt. European Accounting Review, 20, 389-416.

[5] Wang, P. and Lan, J. (2016) Will Mixed Ownership Affect Capital Cost? The Economic and Management Studies, 129-136.

[6] Zou, Y., et al. (2017) Rational Estimation and International Comparison of Capital Cost of Chinese Listed Companies. The World Economic Journal, 1-25.

[7] Li, G. and Liu, L. (2009) Cost of Debt and Private Credit Discrimination. The Financial Research, 137-150.

[8] Chen, H. and Zhou, Z. (2014) Internal Control Quality and Corporate Debt Financing Cost. Nankai Management Review, 17, 103-111.

[9] Ye, D. and Li, X. (2017) CEO Financial Experience and Cost of Debt Capital. The Sanjing Review, 135-152.

[10] Gebhardt, W.R., Lee, C. and Swaminathan, B. (2001) Toward an Implied Cost of Capital. Journal of Accounting Research, 39, 135-176.

[11] Easton, D. (2004) PE Ratios, PEG Ratios, and Estimating the Implied Expected Rate of Return on Equity Capital. The Accounting Review, 79, 73-95.

[12] Ohlson, J.A. and Juettnernauroth, B.E. (2005) Expected EPS and EPS Growth as Determinants of Value. The Review of Accounting Studies, 10, 349-365.

[13] Claus, J. and Thomas, J. (2010) Equity Premia as Low as Three Percent? Evidence from Enalysts' Earnings Forecasts for Domestic and International Stock Markets. Journal of Finance, 56, 1629-1666.

[14] Jiang, F. and Lu, Z. (2006) The Relationship between Diversification and Cost of Capital-Evidence from China's Stock Market. The Accounting Research, 48-55.

[15] Luo, Q. and Wang, Y. (2015) Real Earnings Management and Cost of Equity Capital-An Analysis Based on the Difference in Corporate Growth. The Financial Research, 178-191.

[16] Li, Y., et al. (2016) IFRS, Financial Analysts, Institutional Investors and Cost of Equity Capital-Based on Information Governance Perspective. The Accounting Research, 26-33.

[17] Lin, Z., et al. (2015) Environmental Uncertainty, Diversification and Cost of Capital. The Accounting Research, 36-43.

[18] Wang, P., et al. (2014) Core Reconstruction of Executive Compensation Incentive: Capital Cost Constraint View. The China's Industrial Economy, 109-121.

[19] Zhang, S. and Yang, H. (2014) Accounting Conservatism Choice, Capital Cost and Enterprise Value. The Macroeconomic Research, 97-106.

[20] Shen, H. (2007) Market Segmentation, Cross-Border Listing and Expected Capital Cost-Empirical Evidence from Ohlson-Juettner Model. The Financial Research, 
146-155.

[21] Wang, P., et al. (2015) Study on Differences of Capital Cost with Heterogeneous Shareholders-Also on the Financial Basis of Mixed-Ownership Reform. China's Industrial Economy, 129-144.

[22] Botosan, C.A. and Plumlee, M.A. (2005) Assessing Alternative Proxies for the Expected Risk Premium. The Accounting Review, 80, 21-53.

[23] Fama, E.F. and French, K.R. (1999) The Corporate Cost of Capital and the Return on Corporate Investment. Journal of Finance, 54, 1939-1967.

[24] Zhang, Z., et al. (2004) Cost of Capital and Investment Return of a-Share Listed Companies-From the Perspective of Internal Rate of Return. The Economic Research, 74-84.

[25] Xin, Q., et al. (2007) Estimation of China's Return on Capital Investment and Analysis of Influencing Factors-Experience of Listed Companies from 1999 to 2004. The Economics (Quarterly), 1143-1164.

[26] Zhang, X. (2015) Influence of Financial Supervision and Incentive Mechanism on Cost of Equity Capital. The Statistics and Decision-Making, 170-173.

[27] Zou, Y., et al. (2015) Equity Incentive, Controlling Shareholder and Equity Capital Cost. The Economic Management, 98-109.

[28] Earnings forecasts for domestic and international stock markets: Journal of Finance, 56, 1629-1666.

[29] Wang, B. (2008) Earnings Quality and Cost of Capital-Empirical Evidence from Chinese Listed Companies. The Management Science, 67-73.

[30] Wang, L. (2013) Real Activity Earnings Management and Equity Capital Cost. The Management Science, 87-99.

[31] Yu, H. and Zhang, T. (2006) Information Disclosure, Information Asymmetry and Cost of Capital: Research Review. The Accounting Research, 80-86.

[32] Li, M. and Hui, X. (2008) Information Disclosure and Cost of Capital in Listed Companies: Empirical Evidence from China's Securities Market. The Journal of Management, 88-95.

[33] Zhang, Z. and Deng, B. (2017) Will CSR Report Verification Reduce the Cost of Equity Capital of Enterprises? The Audit Studies, 98-104.

[34] Shen, Y., et al. (2009) Investor Protection and Capital Structure of Listed Companies. The Economic Research, 131-142.

[35] Xu, J., et al. (2017) Will M \& A Goodwill Information Affect Cost of Debt Capital? The Journal of the Central University of Finance and Economics, 109-118. 